Florida A\&M University College of Law

Scholarly Commons @ FAMU Law

The Evolving Intervention Regime in Africa: From Basket Case to Market Place?

Jeremy I. Levitt

Follow this and additional works at: https://commons.law.famu.edu/faculty-research

Part of the International Law Commons, Military, War, and Peace Commons, and the Transnational Law Commons 
This response has taken place in the context of two decades of continental movement toward economic coordination, creation of free trade zones and increased intra-African trade, increased receptivity to foreign investment, and the return of a number of states to democratic governance, including South Africa, Namibia and Nigeria. It has occurred in the context of coordination with UN agencies, new patterns of claims under international law about customary law, humanitarian intervention, pro-democratic intervention, regional and subregional assistance in upholding the freedom of African peoples to determine and protect their choices about governance, and generally much inquiry about the most just and effective strategies for crisis intervention within African states.

The larger international community has noticed. Some states and commentators have continued to try to give Africa lessons in how to govern itself, a trend stretching back some five centuries through European colonialism into the slave trade and slavery. They have denied that Africans could make any positive contributions here at all. But other states and organizations have drawn lessons and examples of new legal doctrine and interpretations, subregional coordination, institution-building, and governance, and have begun adapting them to crises in other regions where new thinking about peace building is needed. Thus we now seem to be in a second phase of African contributions to international law within the last half century. The first phase was produced by the process of decolonization from the late 1950 s to the early 1970s, and the interpretations of international law that it produced. Then African interpretations were contentious because they tended to challenge the continued use of international law to support European dominance. They were contentious, further, because historically peoples of African heritage have generally not been perceived as either capable or authorized to invoke or prescribe international law. Time will tell whether the second-phase African contributions will prove as contentious.

Our panel this afternoon features a group of experienced and notable scholars. We convene to explore the African contributions to the international law of peacekeeping that are emerging.

\title{
THE EVOLVING INTERVENTION REgIME IN AFRICA: FROM BASKET CASE TO MARKET Place?
}

\author{
by Jeremy Levitt
}

\section{INTRODUCTION}

Our topic, "Peacemaking Practices from the South: African Contributions to the Law of Peackeeping," is both unique and dynamic. The title was chosen to qualify and quantify in legal terms in a public forum the evolving intervention regime in Africa. In authoring this evolving intervention regime, African states have proffered the most legally and politically coherent peacemaking frameworks in the world, frameworks that clearly elucidate when groups of states and regional organizations may use force in states for humanitarian purposes.

Historically among the most conservative subscribers to the international law principles of state sovereignty, nonintervention, and territorial integrity, today, only twelve years into the post-Cold War era, African states and regional organizations have adopted, established, and put into action norm-creating mechanisms that are chiseling away at

*Assistant Professor of Law, DePaul University College of Law. 
traditional prohibitions against uses of force outside the authority of the United Nations Security Council (UNSC).

The analysis that follows aims to present dynamic new information about pressing law of the use of force and peacemaking developments in Africa. It is meant to be more descriptive than analytic. It will discuss, among other things, the evolution of the international law of the use of force by assessing state practice and treaty law developments in Africa since the end of the Cold War-developments that undoubtedly form an important part of the evolution of the corpus of general international law.

Space constraints will not permit me to examine the legality of the various African interventions that have taken place since the end of the Cold War (the majority of which took place without UNSC authorization). These include the Economic Community of West African States (ECOWAS) interventions in Liberia, Sierra Leone, Guinea-Bissau, and now Guinea; the Mission for the Implementation of the Bangui Agreement (MISAB) in the Central African Republic (CAR); and the Southern African Development Community (SADC) operation in Lesotho. I will nonetheless discuss the efficacy of the regional frameworks that gave them impetus. ${ }^{1}$ I will also refer to the intervention provisions in the new Constitutive Act of the African Union (AU), which in late 2002 will replace the Organization of African Unity as the premier continental organization in Africa.

Not only is Africa the first region to advance comprehensive intervention regimes, but the ones it advances are leagues ahead of the other regions of the world. African state practice and treaty law developments since the end of the Cold War illustrate that, with some exceptions, African nations have been among the most committed to creating peace both within and outside of Africa.

\section{BIASES IN THE LAW OF THE USE OF FORCE}

In international studies Africa is viewed as a pariah-a basket case, not a market place. In law schools most academic consider African states to be objects rather than subjects of international law. This explains why a significant portion of the wide-body of literature on the law of use of force, and more generally peacekeeping and humanitarian intervention, is heavily biased and flawed. The geopolitical, Eurocentric, and linear bias in Western legal academia is astounding when it is applied to Africa. This is in part due to a lack of Western intellectual interest in the continent; however, international lawyers also typically lack multidisciplinary training and regional expertise, particularly on the developing world.

As a result, topical discussions on, for example, peacekeeping, peace enforcement, humanitarian intervention, and other peacemaking developments in Africa are either uninformed or inadequately analyzed. More often than not, when analysts assess African security issues, they do so with a voice reminiscent of agents of the British Colonial Office in the eighteen th century 18 th century, paternalistic and unaware. This phenomenon is unfortunate. It creates an environment enabling production of analytically weak scholarship on Africa. The academy can do better. It is time to pay closer attention to international law influences from the world's second largest continent, the one with the highest density of states: Africa.

\footnotetext{
' For an analysis of the legality of these interventions see, JeremyLevitt, African Interventionist States and International Law, in Oliver Furley and Roy May (eds.) AFRICAN INTERVENTIONIST STATES (Aldershot: Ashgate Publishing, 2001). Since the MISAB intervention took place under the auspices of an ad hoc group of states rather than a regional organization, it will be referred to only casually in the analysis that follows.
} 


\section{THE ECONOMIC COMMUNITY OF WEST AFRICAN STATES}

In 1975, the ECOWAS was founded by treaty. ${ }^{2}$ Its main aim at the time was to spur economic integration and development in West Africa; regional security was an important but not vital concern. It later adopted the 1978 Protocol on Non-Aggression, and the 1981 Protocol Relating to Mutual Assistance and Defense. ${ }^{3}$ Neither the treaty nor the protocols empowered ECOWAS to launch peacekeeping missions (although the 1981 Protocol did empower it to intervene in conflicts that were "externally engineered").

\section{Liberia}

In 1989, ECOWAS was tested with the Liberian Civil War (1989-1997). International disinterest and inaction by the United Nations and United States forced ECOWAS to intervene in Liberai to halt the war and protect human life.

In November 1992, two full years after ECOWAS intervened in Liberia, the UNSC adopted Resolution 788, which placed an arms and petroleum embargo against Liberia and empowered ECOWAS to enforce its terms. The following year, in September 1993, it adopted Resolution 866, which established the UN Observer Group in Liberia (UNOMIL), where, for the first time in UN history, the UN codeployed forces with another mission (the ECOWAS Cease-fire Monitoring Group (ECOMOG)) already underway. Needless to say, the ECOMOG continued to serve as primary keeper of the peace.

Moreover, between January 1991 and November 1996, the UNSC adopted fifteen resolutions and the president of the UNSC issued nine presidential statements, all relating to the situation in Liberia. Almost every resolution and statement commended ECOWAS for its efforts; asked UN member states to support it financially; encouraged African states to contribute troops to it; and condemned attacks against it by rebel factions. Not once was ECOWAS condemned for inappropriate conduct.

UNSC action thus placed a retroactive de jure seal of approval on ECOWAS intervention; I consider this concrete evidence that a broad right of humanitarian intervention exists. At the least, UNSC action in this case confirmed that an intervention taken outside of the authority of the UN Charter could indeed be legal.

\section{Article 58 of the ECOWAS Revised Treaty}

In July 1993, three years into its "peace creation" mission in Liberia ECOWAS adopted its Revised Treaty of 1993 (Treaty), ${ }^{4}$ in part to provide a basis for future peacekeeping. Article 4(e) of the Treaty states that the contracting parties of the ECOWAS affirm their adherence to the "maintenance of regional peace, stability, and security through the promotion and strengthening of good neighborliness." Article 58 dealing with regional security maintains that peace and security is a key objective of ECOWAS and in pursuit of this objective empowers the organization to "establish a regional peace and security observation system and peace-keeping forces where appropriate." Section 3 of Article 58 also provides for the adoption of protocols on political cooperation and regional peace and stability.

\footnotetext{
${ }^{2}$ Treaty of the Economic Community of West African States (ECOWAS), May 28, 1975 ) (on file with author).

${ }^{3}$ ECOWAS Protocal on Non-Aggression, April 22, 1978, reprinted in 6 REGIONAL PEACE-KEEPING AND INTERNATIONAL ENFORCEMENT: THE LIBERIAN CRISES 18-19 (M. Weller ed., 1994) [hereinafter REGIONAL. PEACE-KEEPING]; ECOWAS Protocol Relating to Mutual Assistance on Defence, May 29, 1981, reprinted in REGIONAL PEACE-KEEPING, at 19-24.

${ }^{4}$ Economic Community of West African States Revised Treaty, Article 58 Regional Security, July 24, 1993 (on file with author).
} 


\section{Sierra Leone}

In an attempt to avert the toppling of the democratically elected government of Sierra Leone by both military and insurgent elements and to forestall intense civil conflict, the head of state of Nigeria and the authority of the heads of state and government of ECOWAS (AHSGECO) relied on Article 58 to justify their interventions in Sierra Leone in May and August of 1997, although there were other legal bases for these interventions. ${ }^{5}$ In October 1997, the UNSC supported the ECOWAS intervention in Sierra Leone by adopting Resolution 1132, which imposed an arms and petroleum embargo and travel restrictions against the junta. It also empowered ECOWAS to enforce its terms.

\section{The ECOWAS Framework}

In October 1998, some fourteen months after the interventions in Liberia and Sierra Leone and in an effort to consolidate its capacity for preventing, managing, and resolving conflict, the AHSGECO adopted a binding mechanism to allow for interstate collaboration in the collective management of regional security: the Framework for the Mechanism for Conflict Prevention, Management, Resolution, Peace-keeping and Security $^{6}$ (Framework). The Framework sets out an elaborate scheme for ECOWAS-ECOMOG enforcement operations, including a coherent command and control structure. It calls for the creation of an ECOWAS Mediation and Security Council to, among other things, authorize all forms of intervention, including military. It also draws an interesting distinction between interstate and intrastate conflict.

In internal conflict situations that are sustained and maintained from within, Paragraph $\mathbf{4 6}$ of the Framework provides for military intervention by ECOWAS when situations: (1) threaten to trigger a humanitarian disaster; (2) pose a serious threat to peace and security in the subregion; and (3) follow the overthrow or attempted overthrow of a democratically elected government. Except for the SADC and the new AU, no other regional organization has laid down a normative framework for unilateral military intervention in interstate or intrastate conflict. Furthermore, Paragraph $\mathbf{5 2}$ of the Framework provides, among other things, that the ECOMOG may undertake military operations for peacekeeping; humanitarian intervention in support of humanitarian actions; and the enforcement of sanctions and embargos. ECOWAS is thus the first regional arrangement to codify both humanitarian and pro-democratic rights of intervention.

\section{Guinea-Bissau}

Ironically, the Framework, which had been in ECOWAS bureaucratic pipeline for quite some time, was adopted just over a month before ECOWAS dispatched ECOMOG to Guinea-Bissau in December 1998. ECOMOG replaced Senegalese and Guinean troops who had intervened in June 1998 to save the sitting government from a mutiny by high-ranking officers of its armed forces and to avert mass civil conflict between loyalist and opposition forces. It deployed ECOMOG for the following reasons: (1) to monitor the peace and imposition of a Government of National Unity; (2) to guarantee security along the Senegalese/Guinean border; (3) to keep the warring parties apart;

\footnotetext{
${ }^{5}$ See Jeremy Levitt, Humanitarian Intervention by Regional Actors in Internal Conflicts: The Cases of ECOWAS in Liberia and Sierra Leone, 12 TEMPLE INT'L \& CoMP. L.J. 363 (1998).

${ }^{6}$ Framework Establishing the ECOWAS Mechanism for Conflict Prevention, Management, and Resolution, Peace-keeping, and Security, meeting of Ministers of Defence, Internal Affairs and Security, Banjul, July 23-24, 1998, adopted, Heads of State meeting, Abuja, October 30-31, 1998, in AFRICAN LEGALMATERIALS, AFR. J. INT'L \& COMP. L. 148 (Mar. 1999).
} 
and (4) to guarantee free access to humanitarian entities. What is interesting here is that on December 26, 1998, less than one week before ECOMOG deployed in GuineaBissau, the UNSC adopted Resolution 1216, which approved of the ECOMOG mission and recognized that it might need to employ force to effectuate its mandate.

\section{The ECOWAS Protocol}

In December 1999, approximately one year after the Framework was adopted and the ECOWAS authorized the Guinea-Bissau operation, it adopted the Protocol Establishing the Mechanism for Conflict Prevention, Management, Resolution, PeaceKeeping and Security $^{7}$ (Protocol), which aims to further implement Article 58 of the Revised Treaty. A key objective of the Protocol is to prevent, manage, and resolve internal and interstate conflict-and here it states that Paragraph 46 of the Framework is controlling on these matters. Like the Framework, Article 22 of the Protocol states that peacekeeping and the restoration of peace; humanitarian intervention in support of humanitarian disaster; and enforcement of sanctions including embargoes are key responsibilities of ECOMOG. Article 22 does not recognize the authority of the UNSC in either adjudicating nor maintaining international peace and security matters. Perhaps this is a positive development, given the UN's dismal record in Liberia, Somalia, Rwanda, the Central African Republic (CAR), Guinea-Bissau, and Sierra Leone-just to mention a few UN operations.

Article 25 of the Protocol complements Paragraph 46 of the Framework, stating that the mechanism may take enforcement action in internal conflicts in situations: (1) where there is a threat of a humanitarian disaster or a serious threat to peace and security in the subregion; (2) where there has been a serious and massive violation of human rights and the rule of law; and (3) where there has been an overthrow or attempted overthrow of a democratically elected government. For these very reasons ECOWAS sought to establish an ECOMOG force along the borders of Guinea and Liberia in December 2000, to prevent border skirmishes between the two countries from escalating into full-blown conflict.

This is the background for the development of ECOWAS law, which has evolved progressively over the past twelve years to meet the growing security challenges in West Africa. ECOWAS law not only lays down an unambiguous framework for the protection of human rights, democracy, and the rule of law, it also codifies both humanitarian and pro-democratic rights of intervention. The revolutionary evolution of ECOWAS law comes at the behest of West African nations, who have time after time demonstrated their willingness to forfeit sovereignty for peace and security.

Notwithstanding the ECOWAS is not wholly unique in this respect. The SADC has proffered similar regional security structures.

\section{THE SOUTH AFRICAN DEVELOPMENT COMMUNITY}

The SADC Treaty and Organ

In January 1992 the Council of Ministers of the Southern African Development Coordination Conference (SADCC), decided to convert SADCC, which had been founded by the then-front line states and was preoccupied with reducing regional dependence on apartheid South Africa, into SADC-the Southern African Development Community. This move appears to have been in part inspired by the changing

\footnotetext{
${ }^{7}$ Protocol Establishing the ECOWAS Mechanism for Conflict Prevention, Management, and Resolution, and Peace-keeping, and Security, UN Doc. A/DEC.12/10/99, Lome, Togo, Dec. 10, 1999 (on file with author).
} 
political environment in South Africa in the wake of Nelson Mandela's release from prison in 1990 and the ongoing efforts to fully dismantle the country's apartheid system. In October 1993 the new SADC Treaty entered into force. ${ }^{8}$ One of its primary objectives is to "promote and defend peace and security" in the Southern African region.

In June 1996 the Authority of the Heads of State and Government of SADC (AHSG) adopted the SADC Organ for Politics, Defense and Security (Organ).$^{10}$ Key aims of the Organ are to protect the people and development of the region against the breakdown of law and order and against interstate and intrastate conflict. The Organ supports cooperation in regional security through conflict management and by coordinating the participation of member states in international and regional peacekeeping.

Objective (g) of the Organ states that where diplomatic efforts fail the Organ is responsible for recommending punitive measures to the Summit of the Heads of State of SADC. It also states that measures to be taken in this regard would be further elaborated in a Protocol on Peace, Security and Conflict Resolution.

\section{The SADC Protocol}

In 1997, the SADC Summit adopted the Protocol on Politics, Defense and Security in the SADC Region. ${ }^{11}$ Under the SADC Protocol, protection people from instability arising from the breakdown of law and order; engaging in conflict prevention, management, and resolution; and promoting peacemaking and peacekeeping to achieve sustainable peace and security are all core functions. Furthermore, like Paragraph 46 of the ECOWAS Framework, Article 5(2) of the Protocol sets out an elaborate criteria for when regional intervention in internal conflicts is justified: when there is (1) largescale conflict violence between sections of the population of a state, or between the state or its armed or paramilitary forces and sections of the population; (2) a threat to the legitimate authority of the government (such as a military coup by armed or paramilitary forces); (3) a condition of civil war or insurgency; (4) or any crisis that could threaten the peace and security of other member states. The SADC Protocol states that in cases of internal conflict the Organ "shall respond to an invitation by a member country to become involved in mediating a conflict within its borders."

Hence, one key distinction between the law of ECOWAS and SADC is that the latter appears to be more conservative; it seems to require that a country consent to an intervention, while ECOWAS law clearly does not. Moreover, Article 2 (g) seems to recognize an ambiguous role for the OAU and the United Nations in "endorsing" SADC operations that entail the use of force. The ECOWAS Framework and Protocol do not make such an acknowledgment. Yet the SADC did not seek any such endorsement before launching its operation in Lesotho in 1998. Moreover, both the SADC and ECOWAS treaty regimes have similar criteria for intervention, and both seem to provide for a prodemocratic right of intervention.

\section{Lesotho}

In 1998, when segments of the civilian population in Lesotho, including opposition party supporters and rogue elements in the sitting government, supported a mutiny by

\footnotetext{
${ }^{8}$ CONTEMPORARY INTERNATIONAL ORGANISATIONSAND TREATIES: SELECTED DOCUMENTS, INSTITUTE FOR STRAteGiC STUdies UnIVERSTTY OF PrEtoria (Ad hoc Pub. No. 34) 91-93 (M. Hough \& A Du Plessis eds., Oct. 1997).

${ }^{9}$ Id . at 95, Art. 5, Objective (c).

${ }^{10}$ The Southern African Development Community (SADC) Organ for Politics, Defence and Security, Gaborone, Botswana, June 28, 1996, in Africa: Selected Documents on Political, SeCurity, HumaniTARIAN AND ECONOMIC ISSUES, INSTITUTE FOR STRATEGIC STUdiEs UnIVERSITY OF PRETORIA (Ad hoc Pub. No. 33) 32-35 (M. Hough \& A Du Plessis eds., Nov., 1999).

${ }^{11}$ Protocol on Politics, Defence and Security in the Southern African Development Community (SADC) Region, in AFriCAN LEGAL MATERIALS, AFR. J. INT'L \& COMP. L. 197 (Mar. 1999).
} 
junior military officers, the small landlocked country plummeted into mass chaos. The situation quickly intensified as loyalist and opposition forces composed of divided segments of the army, police, and the civilian population clashed violently on the streets of Maseru, the capitol. When the situation became intolerable, and at the request of the lawful government, South Africa and Botswana, acting under the veil of SADC, launched a robust intervention to thwart any attempt at a coup d'etat and to restore law and order to the country in accordance with SADC agreements, namely the Protocol. And unlike ECOWAS entering into Liberia, Sierra Leone, and Guinea-Bissau, when SADC (South Africa and Botswana) launched its operation in Lesotho, the complete legal framework for the intervention was already in place.

\section{THE NEW AFRICAN UNION}

The Constitutive Act of the African Union (Union) came into force in March 2001. ${ }^{12}$ The Act lays out a completely new governance framework for the African continent-its EU-like structure varies considerably from that of the OAU.

Article 4 of the Union entitled Principles of the Union, includes three very important provisions on the regional security or peacekeeping front: Provision $(\mathrm{h})$ accords the Union the right to "intervene in a Member State pursuant to a decision of the Assembly in respect of grave circumstances, namely: war crimes, genocide and crimes against humanity." Provision ( $\mathrm{J}$ ) accords member states the "right . . . to request intervention from the Union in order to restore peace and security." Provision ( $p$ ) "condemns and rejects unconstitutional changes of government" (think of the OAU Sierra Leone example). These provisions complement and "continentalize" those enumerated in the ECOWAS Framework and Protocol and SADC Protocol.

The willingness of African states to codify criteria for military intervention and openly condemn undemocratic seizures of power in the instrument constituting the continent's foremost political body is astounding. Even more surprising is the fact that African nations have given the $\mathrm{AU}$ the authority to invoke a right of humanitarian intervention-the best evidence of their commitment to achieve peace, security, and stability on the continent.

\section{CONCLUSION}

This seemingly new African liberalism about regional security is chiseling away at the absolutist/positivist structure of state sovereignty and nonintervention, which is giving way to the logic responding to the harsh realities of a continent marred by deadly conflict. While political elites often have mixed motives for supporting particular policy prescriptions, both democrats and autocrats alike recognize that intrastate, interstate, and regional peace and security are precursors to an environment enabling authentic political and economic development. Both reformers and thieves recognize that stability is necessary, whether to effect positive change or to pilfer the state's wealth; hence, there are incentives for both democrats and autocrats to secure a conflict-free environment. This may explain the general consensus among political elites in Africa to endow regional bodies with the authority to use force in states under limited circumstances.

\footnotetext{
${ }^{12}$ Constitutive Act of the African Union, Adopted by the Thirty-Sixth Ordinary Session of the Assembly of Heads of State and Government, 11 July 2000 -Lome, Togo. The Act came into force eight months later (Mar. 2001) after receiving ratification by two-thirds of the member states of the OAU.
} 
Whatever the case may be, it is unambiguously clear that African states and their organizations have proffered the world's most advanced legal and sociopolitical frameworks to combat conflict and regional insecurity. No other nations or regions have offered comparable structures-nor have they demonstrated a similar willingness to sacrifice human and tangible resources and sovereignty for peace and security. The new African interventionism has influenced state behavior both inside and outside Africa, and state practice and treaty law developments have added significant weight to the development of the corpus of international law and policy, particularly on peacekeeping, peace enforcement, humanitarian intervention, and pro-democratic intervention.

\section{Pro-DEMOCRATIC INTERVENTION IN AFRICA}

\section{by David Wippman}

When the United States invaded Panama in 1989, the international reaction was overwhelmingly hostile. The UN General Assembly and the Organization of American States (OAS) voted overwhelmingly to condemn the intervention, even though it was evident to everyone that the advent of democracy in Panama had been blocked only by General Noriega's refusal to seat the democratically elected government of Guillermo Endara, and even though Endara and most Panamanians welcomed the U.S. invasion. At the time, most states firmly adhered to the view that foreign states could not legitimately use armed force to seat a democratically elected government against the will of an indigenous political elite in effective control of the state.

The world has come a long way since 1989, and, rhetorically at least, Africa has perhaps come the furthest. The United Nations, the Organization on Cooperation and Security in Europe (OCSE), and the OAS, among others, have adopted treaties, declarations, and other instruments reaffirming democracy as the only legitimate form of governance; the OCSE and the OAS have pledged to take action to reverse any unconstitutional overthrow of a democratic government. Africa has joined the trend, and contributed to what Thomas Franck labeled the emerging democratic entitlement through a series of intra-African documents insisting on the promotion of democracy in the region.

Perhaps most notable is the Organization of African Unity's Declaration on a Framework for an OAU Response to Unconstitutional Changes in Government, adopted in July 2000 after a meeting in Lome. ' The declaration, expressing grave concern at the phenomenon of coups d'etat, rejects the unconstitutional seizure of power as an unacceptable violation of the OAU's basic principles. The Declaration reaffirms OAU members' common commitment to democracy. It articulates a set of agreed principles of democratic governance, including constitutionalism, separation of powers, an independent judiciary, political pluralism, respect for democratic change and space for political opposition, free and regular elections, and respect for human rights.

More important, the Declaration specifies a progressive OAU response to unconstitutional seizures of power or "the refusal by an incumbent government to relinquish power to the winning party after free, fair and regular elections." At the request of any member, the OAU Central Organ will condemn the unconstitutional action and suspend the affected government's participation in the OAU. If democracy is not restored within six months, the Central Organ is to institute "a range of limited and targeted

\footnotetext{
" Professor of Law, Cornell Law School.

' AHG/Decl. 5 (XXXVI) (2000).
} 